\title{
Fluctuating salinity levels and an increasing pollution gradient on fish community structure and trophic levels in a small creek in the Niger delta, Nigeria
}

\author{
Francis O. Arimoro $\cdot$ Robert B. Ikomi • \\ Francis O. Nwadukwe • Ovie D. Eruotor • \\ Augustine O. Edegbene
}

Received: 19 June 2014/ Accepted: 17 September 2014/Published online: 3 October 2014

(C) The Author(s) 2014. This article is published with open access at Springerlink.com

\begin{abstract}
Assessing the ecological status of rivers, creeks, and streams is a fundamental and increasingly important water management issue worldwide. This study examines the variations in fish community structure along an increasing pollution gradient in a small Niger Delta creek in Nigeria in both time and space. Salinity of the area fluctuated between fresh and mesohaline brackish waters with values ranging from 0.4 to 5.2 PPT and electrical conductivity values ranging between 16.9 and $136.0 \mu \mathrm{S} / \mathrm{cm}$. The site in the upper creek (Site 1) was relatively free from gross pollution, with significantly high dissolved oxygen levels and low nutrient and salinity levels. Site 3 recorded relatively higher values of 5-day biochemical oxygen demand $\left(\mathrm{BOD}_{5}\right)$ and high nutrient levels, indicating substantial input of organic matter to the creek upstream. Six (6) species, Tilapia guineensis (Cichlidae), Bostrychus africanus (Eleotridae), Hemichromis fasciatus (Cichlidae), Ethmalosa fimbriata (Clupeidae), Gerres melanopterus (Gerreidae), and Clarias macromystax dominated the sample and accounted for about $70 \%$ of the total catch. Tilapia guineensis constituted the major dominant species and accounted numerically for about $20 \%$ of the total catches and $45 \%$ of the total biomass. Multi-species fisheries dominate the coastal zone with Tilapia guineensis, Gerres melanopterus and Ethmalosa fimbriata, Liza falcipinus, Mugil spp., and Chrysichthys nigrodigitatus, the major species in the commercial catches. Canonical correspondence analysis indicated that dissolved oxygen, electrical conductivity, total nitrogen, $\mathrm{BOD}_{5}$, and temperature were important variables structuring the overall fish assemblages. Overall, salinity was the major environmental variable determining the diversity of fish communities at the various sites. The effect of anthropogenic activities and land use practices around the creek only marginally affected the abundance of the fish species but not the diversity. These findings indicate that the water body is still useful as a good fishing ground for the rural communities and every effort should be put in place to ensure its protection and conservation for the production of healthy fish.
\end{abstract}

Keywords Ajijiguan creek · Fish communities · Salinity levels · Physicochemical parameters · Trophic levels

F. O. Arimoro $(\bowtie) \cdot$ A. O. Edegbene

Applied Hydrobiology Unit, Department of Biological Sciences, Federal University of Technology, P.M.B. 65, Minna,

Nigeria

e-mail: fransarimoro@yahoo.com

R. B. Ikomi - F. O. Nwadukwe - O. D. Eruotor

Department of Animal and Environmental Biology, Delta State University, PMB 1, Abraka, Nigeria 


\section{Introduction}

Freshwater systems across much of the African continent including Madagascar are under increasing pressure from the combined onslaught of introduced species, pollution from burgeoning populations and industries, dams and water extractions, and overall land use change (Thieme et al. 2005). This multitude of threats on a wide front requires conservationists to establish priorities and to set goals and targets for the conservation of aquatic systems and their rich biodiversity. The numerous creeks in the Niger Delta serve various functions such as sources of potable water, economic uses including artisanal fisheries, recreation as well as for its esthetic value. The Ajijiguan creek is one of the small creeks located in the Niger Delta area. It is an important creek due to its proximity to the downstream estuarine Benin River and upstream freshwater Ethiope River. Generally, creeks are characterized by many interacting physical factors that produce spatial and temporal heterogeneity and may exert a major influence on benthic communities and fish (Arimoro et al. 2006; Salgado et al. 2007; Ekeke et al. 2008; Adite et al. 2013). Fish, as a source of "rich food for poor people", can play an important role in improving Africa's food security and nutritional status; more than 200 million Africans eat fish regularly (World Fish Center 2005). Fresh, but more often smoked, dried, or even as powder, fish is a critical source of dietary protein and micronutrients for many communities in the coastal areas around these water bodies. Fish may also be the sole accessible and/or affordable source of animal protein for poor households in urban or peri-urban areas (FAO 2003; Delgado et al. 2003; World Fish Center 2005). The continuous existence of fish in the whole of Nigeria and especially in the Niger Delta is currently being jeopardized as a result of pollution from anthropogenic activities (Arimoro et al. 2006, Ekeke et al. 2008; Obasohan and Oronsaye 2009; Ogamba et al. 2014). Therefore, studies of this nature are needed to provide cues for conservation and effective planning and management of Afrotropical aquatic resources. In carrying out this study, we tried to answer the following question: does the spatial and temporal distribution of fish communities in the creek resemble those of other Afrotropical regions? We hypothesized that the environmental water quality variables would predict fish assemblages.

The principal objectives of the study were:

1. To characterize fish communities in the creek in terms of taxonomic richness, diversity, trophic levels, and seasonality;

2. To investigate relationships between fish communities and selected environmental factors using canonical correspondence analysis (CCA).

\section{Materials and methods}

Study area

The study was carried out in Ajijiguan creek, a tributary of the Benin River in the Niger Delta area of Nigeria, which lies between $5^{\circ} 30^{\prime}$ to $6^{\circ} 00^{\prime} \mathrm{E}$ and $5^{\circ} 30^{\prime}$ to $6^{\circ} 00^{\prime} \mathrm{N}$ covering a total area of $1.8 \mathrm{~km}^{2}$ within Nigeria (Fig. 1). The study area shows the characteristic tropical climate of two distinct seasons; the dry (November-April) and the wet (May-October). The mean annual temperature is about $28{ }^{\circ} \mathrm{C}\left(22-34{ }^{\circ} \mathrm{C}\right)$ while the mean annual relative humidity is $85 \%$. The creek connects the freshwater River Ethiope and downstream estuarine Benin River. It begins from a branch from the lower reaches of the River Ethiope and passes through the towns of Ogharefe, Ajagbodudu, Oghareki, Ubakana, before joining the estuarine portion of the Benin River. The river substratum consists mainly of fine sand mixed with mud and occasionally with coarse sand and pebbles. Decaying macrophytes and debris also form part of the substratum. Three sites were chosen along this river system from the head water to the down reaches.

Site 1 is approximately $500 \mathrm{~m}$ from River Ethiope (Fig. 1). The water flows through an open channel (15.4 $\mathrm{m}$ wide at the site). Aquatic vegetation consists of both submerged and floating macrophytes (Ceratophyllum submersum, Nymphaea lotus, Ecchornia crassipes, Utricularia spp.) The streambed is muddy and silted with fallen leaves. The riparian vegetation is composed of terrestrial plants including oil palm (Elaeis guineensis) and shrubs such as Acrosticuum aureum, Ficus, and Alchornea spp. Water velocity at this site is 


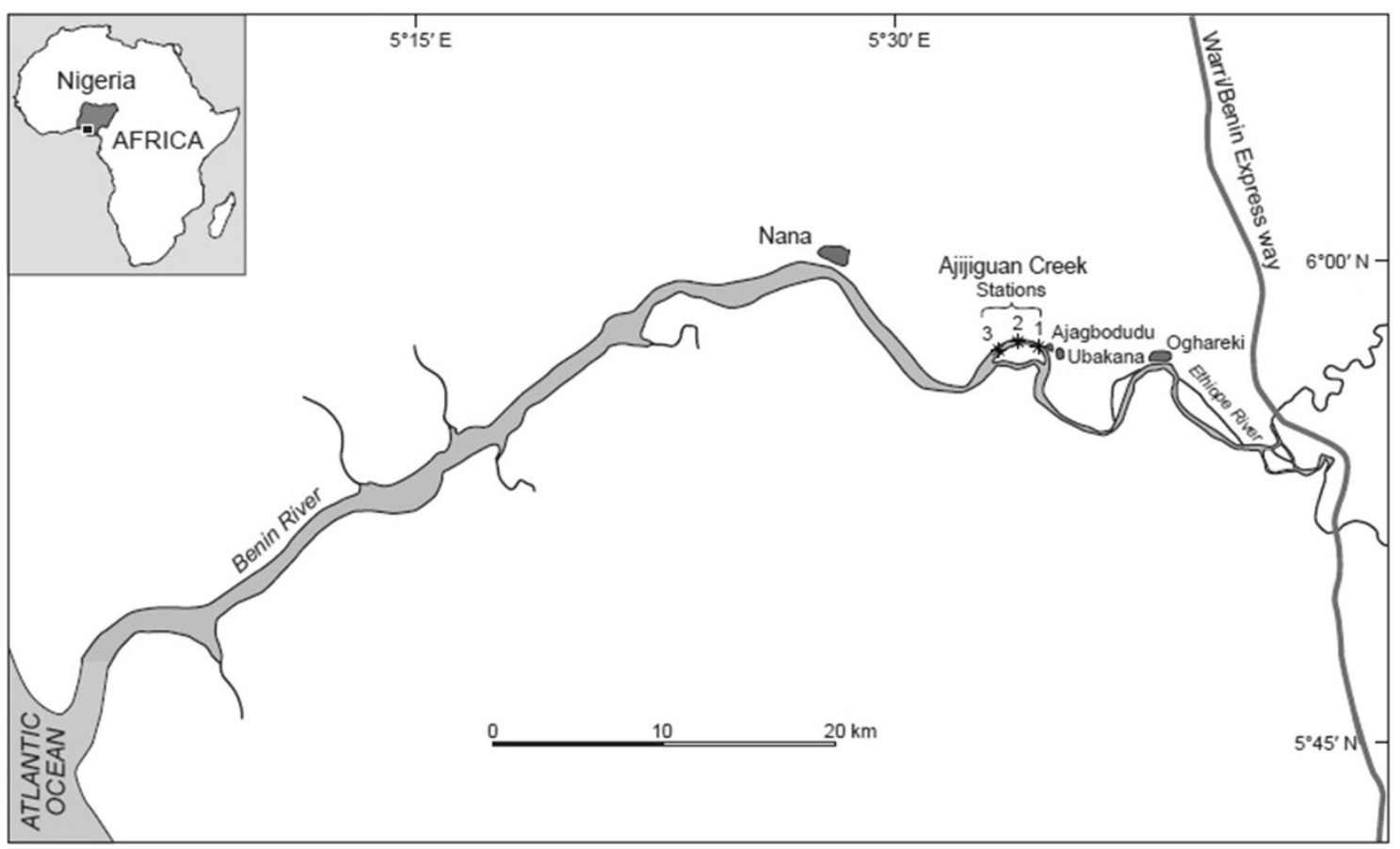

Fig. 1 Map of the study area showing the sampling sites of Ajijiguan creek, Niger Delta, Nigeria

slow with a mean of $0.17 \mathrm{~m} \mathrm{~s}^{-1}$. The site is relatively free from human activities perhaps for its location which is far from human settlement.

Site 2 is $10.4 \mathrm{~m}$ wide, $0.34-0.62 \mathrm{~m}$ deep with flow velocities ranging from 0.16 to $0.24 \mathrm{~ms}^{-1}$. The vegetation consists mainly of Commelina, Nymphaea sp., Panicum repens, Pistia stratiotes, and Echhornia crassipes. The streambed is composed of silt and clay. Artisanal fishing is the main anthropogenic activity in this area with occasional domestic uses like washing of clothes and bathing.

Site 3 is located $2 \mathrm{~km}$ downstream of Site 2 in Ajagbodudu town and $0.43-0.80 \mathrm{~m}$ deep at the shallow portion of sampled areas with an estimated width of $12.5 \mathrm{~m}$. The flow velocity here is relatively fast $\left(0.22-0.31 \mathrm{~ms}^{-1}\right)$ when compared to the other two sites. The streambed consists of mud and clay with fallen leaves. The riparian vegetation is composed of terrestrial plants including oil palm (Elaeis guineensis), Musanga sp., Musa sp. and shrubs such as Acrosticuum aureum, Ficus sp., Alchornea sp., and mangrove plant, Rhizophora sp. Artisanal fishing is the main anthropogenic activity in this area with occasional washing of clothes and domestic discharge consisting of refuse and kitchen wastes from the populated settlement along its route. This site is influenced by the tidal fluctuations of the Benin estuary.

Physicochemical parameters

Surface water at each sampling site was sampled once each month. At each sampling site the following physicochemical parameters were measured: depth using a calibrated stick. Flow velocity was measured in the mid channel on three occasions by timing a float (average of three trials) as it moved over a distance of $10 \mathrm{~m}$ (Gordon et al. 1994). Dissolved oxygen (YSI 55 dissolved oxygen meter), temperature, pH, electrical conductivity, and TDS were measured with a multi-probe meter (Hanna HI 991300/1). Water samples were taken for analysis of total nitrogen and phosphates. Measurements were achieved spectrophotometrically after reduction with appropriate solutions [APHA (American Public Health Association) 1998]. Salinity, alkalinity, and biochemical oxygen demand $\left(\mathrm{BOD}_{5}\right)$ were determined in the laboratory using APHA (1998) methods.

Fish sampling and laboratory analyses

The creek was systematically sampled to provide sufficient data to describe the local dry-season and wetseason fish communities, to cover all habitat units present in the study area. The sample locations for the study 
were selected to include representative riverine and brackish aquatic habitats around the creek. Samples of fish collected from the fishermen in these sampling locations were identified and studied. Sampling was stratified to include an equivalent amount of effort in the three sampling sites within the creek. Hired fishermen sampled using trap net and cast nets. Effort was also applied equally between sections. Pipes, basket traps, and beach seine efforts were applied opportunistically where shallow habitat conditions were suitable for these techniques to be applied. Setlines were deployed for an overnight period in suitable deepwater locations on the creek.

Some fish samples (an average of 5 specimens belonging to the same species) were each weighed using a Mettler E 200 top loading balance and the body weights were recorded in gram (The standard lengths were recorded in $\mathrm{cm}$ using a measuring board. The length-weight relationship of the fish described by Bagenal (1978) was adopted, i.e. $W=a L^{b}$, where $W$ weight in grams, $L$ standard length in centimeters, and $a$ and $b$ are regression constants. The condition factor $(K)$ was calculated from data obtained from the length and weight measurement using the equation $K=100 \mathrm{~W} / L 3 \ldots$ (Bagenal 1978).

The gut of each specimen was removed and preserved in $10 \%$ formalin. Each stomach was cut open and its contents washed into Petri-dish using $4 \%$ formalin (Obasohan and Oronsaye 2009). The food items were identified, counted, and analyzed using frequency of occurrence, fullness, volumetric, gravimetric, and numerical methods (Hyslop 1980). Fish species were assigned to trophic groups by the observation of their gut content and from literature. Fish species were assigned the following fishery importance: highly commercial (HC), moderately commercial (MC), and no value (NV) according to Adite et al. (2013). The gonadosomatic index, abbreviated as GSI, is the calculation of the gonad mass as a proportion of the total body mass. It is represented by the following formula: GSI $=[$ Gonad weight/total tissue weight $] \times 100$ (Barber and Blake 2006). It is a tool for measuring the sexual maturity of animals in correlation to ovary development.

\section{Data analysis}

The range, mean and standard deviation for each parameter and site were calculated. Physicochemical parameters of sites were compared using one-way ANOVA on $\log (x+1)$ transformed data except for $\mathrm{pH}$. Fixed effect ANOVAs were performed using dates as replicates. Significant ANOVAs $(P<0.05)$ were followed by post hoc [Tukey Honest (HSD)] tests to identify differences between sites means. Seasonal variation in the faunal abundance between the dry and wet seasons was examined by applying the $t$ test to compare each set of samples in the three sampling sites.

Capture per unit effort (CPUE) was determined by dividing the catch (number of fish caught) by the effort (fishing time). CPUE was determined for commercial species in each reach and gear type (e.g. trap net, seine net, hook and line) and a total CPUE for each reach. It was then compared between reaches to determine the greatest relative abundance for each species. Due to small sample sizes and the likelihood that the data will not be normally distributed, Kruskal-Wallis test (a nonparametric ANOVA) was used to determine if there are statistically significant differences in CPUE between reaches. Relative abundance was determined by species for each reach.

Canonical correspondence analysis (CCA) was used to evaluate correlations between fish communities and environmental variables with PAST statistical package (Hammer et al. 2001). CCA is a powerful tool for simplifying complex data sets and, being a direct gradient analysis, it allows integrated analysis of both taxa and environmental data (terBraak and Smilauer 2002). Before using CCA, variables that covaried with other variables (Pearson correlation $r>0.90, P<0.05$, such as BOD) were removed. Rare species $(<1 \%$ of total abundance at a sampling site) were not included in the CCA. Although all physicochemical parameters were included in the early CCA ordinations, those variables with high variance inflation factors (VIF $>20$ indicating very strong multicollinearity) were eliminated from the analyses. In addition, variables were log transformed $[\log (x+1)]$ before the CCA analysis to prevent extreme values (outliers) from unduly influencing the ordination. Species-environment correlation coefficients provided a measure of how well variation in community composition could be explained by individual environmental variables. A Monte Carlo permutation test with 199 permutations (Jckel 1986) was used to assess the significance of the canonical axes extracted. Taxa richness (Margalef and Menhinick indices), diversity (Shannon and Simpson dominance indices), and evenness indices were calculated using PAST statistical package (Hammer et al. 2001).

Cluster analysis to show association between the sites was calculated using Bray Curtis similarity index in PAST statistical package (Hammer et al. 2001). 


\section{Results}

Physicochemical parameters

The mean and standard deviation of the physicochemical parameters of the sampling sites, and their significant differences, are shown in Table 1. Significantly higher values $(P<0.05)$ of electrical conductivity, BOD, nutrient [total nitrogen $\left(87.75 \pm 22.44 \mu \mathrm{g} \mathrm{L}^{-1}\right)$, total phosphorus $\left(52.5 \pm 17.56 \mu \mathrm{g} \mathrm{L}^{-1}\right)$ ] and salinity levels $\left(3.85 \pm 0.79 \%\right.$ ) , and lower dissolved oxygen concentrations $\left(5.04 \pm 0.28 \mathrm{mg} \mathrm{L}^{-1}\right)$ were recorded at Site 3 compared to Site 1 and 2. Tukey's honest test for multiple comparisons carried out between sites showed that Site 3 means were different from the other two sites. The $\mathrm{pH}$ did not show variation within the sites examined. Flow velocity and depth increased from Site 1 to 3 and steadily with time during the incoming flood from the watershed in the wet season, whereas temperature decreased from November to June, being lowest in the wet season. Salinity increased from November to February at all the sites, but decreased with the coming of the rains in the wet season (Fig. 2). Flow velocity and water depths were significantly different $(P<0.05)$ between the wet and dry seasons

\section{Fluctuations in salinity levels}

Temporal and spatial variation in salinity of Ajijiguan creek during the period of the study is shown in Fig. 2. Salinity increased progressively at all sites and peaked in the month of February with slight fluctuation afterwards to the end of June. Clearly, salinity was significantly $(P<0.05)$ higher in Site 3 throughout the period of study.

Fish assemblage in the sampling sites

A summary of the fish assemblage of the various fish species collected from the study area is presented in Table 2. Overall, 56 fish species belonging to 26 families were collected in the water bodies consisting of both freshwater and salt water species with a total of 1,869 individual fish. A greater number of the fish species were pelagic, which moved within the upper strata of the water column. Cichlidae (5 species), Eleotridae ( 3 species), Mugilidae (5 species), and Mochokidae (4 species) were the most dominant families. Six (6) species, Tilapia guineensis (Cichlidae), Bostrychus africanus (Eleotridae), Hemichromis fasciatus (Cichlidae), Ethmalosa fimbriata (Clupeidae), Gerres melanopterus (Gerreidae), and Clarias macromystax dominated the sample and accounted for about $70 \%$. Tilapia guineensis constituted the major dominant species and accounted numerically for about $20 \%$ of the total catches and $45 \%$ of the total biomass. Multi-species fisheries dominated the creek with the major species in the commercial catches: Tilapia guineensis, Gerres melanopterus and Ethmalosa fimbriata, Liza falcipinus, Mugil spp and Chrysichthys nigrodigitatus.

Fish and environmental relationships

The CCA ordination revealed strong relationships between species abundances and measured environmental variables. The first canonical axis accounted for $77 \%$ of the variation in the data set. An unrestricted Monte Carlo permutation test indicated that axes 1 and 2 were significant $(P<0.05)$. The main environmental gradient (Axis 1) was strongly positively determined by temperature and dissolved oxygen and the fauna strongly associated with these parameters were represented by most fish species taken from Site 1 such as Hemichromis fasciatus, Synodontis eupterus, Clarias gariepinus, etc., (Fig. 3; Table 3). The environmental variables that were strongly negatively corrected with axis 1 were Salinity, total nitrogen, electrical conductivity, and depth and represented by most of the species collected from site 3 such as Elops lacerta, Lutjanus goriensis, Ethmalosa fimbriata, and Galeiodes species. Generally, samples taken from Sites 1 and 2 were positioned on the right, whereas those from Sites 3 were positioned on the left. Site 2 shared several taxa with site 1 and 2 and was not strongly associated with any species. The second axis was positively correlated with electrical conductivity and negatively correlated with flow velocity $\mathrm{pH}$ and alkalinity (Fig. 3; Table 3). The cluster analysis produced (Fig. 4) clearly showed the association between the sites. Values closer to 0.24 were dissimilar by Bray Curtis similarity. Site 3 was dissimilar with the other sites. 


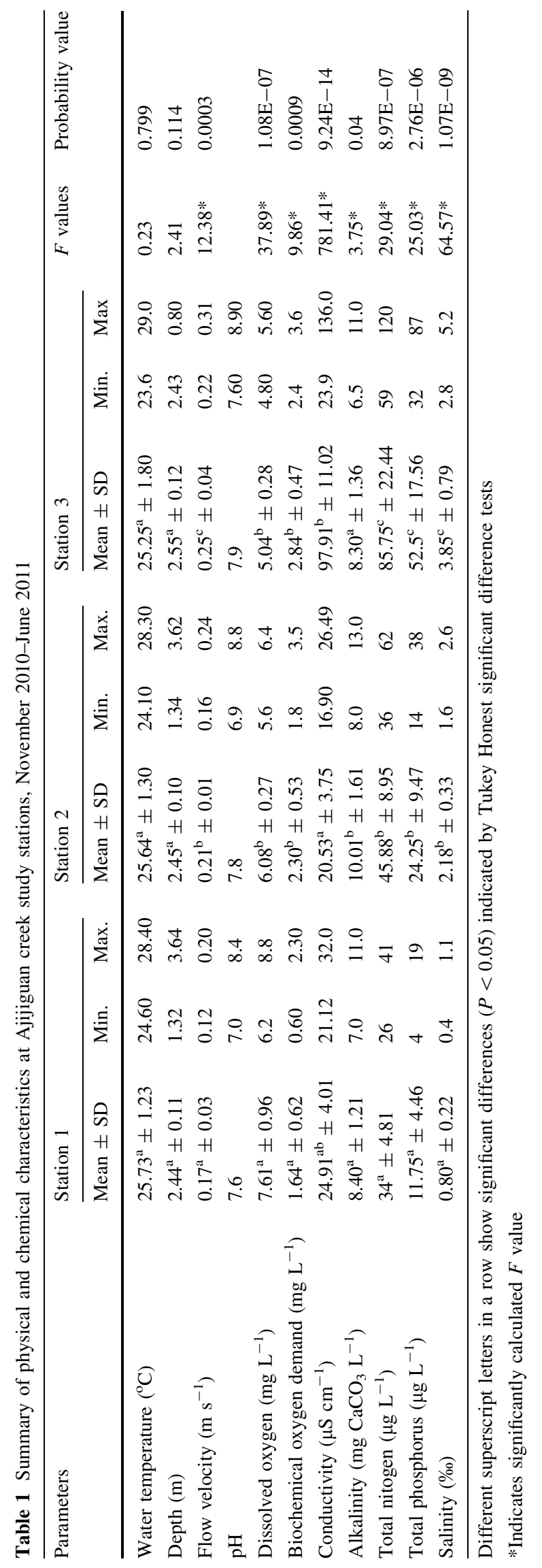


Fig. 2 Temporal and spatial variation in salinity of Ajijiguan creek, Niger Delta, from November 2010 to June 2011

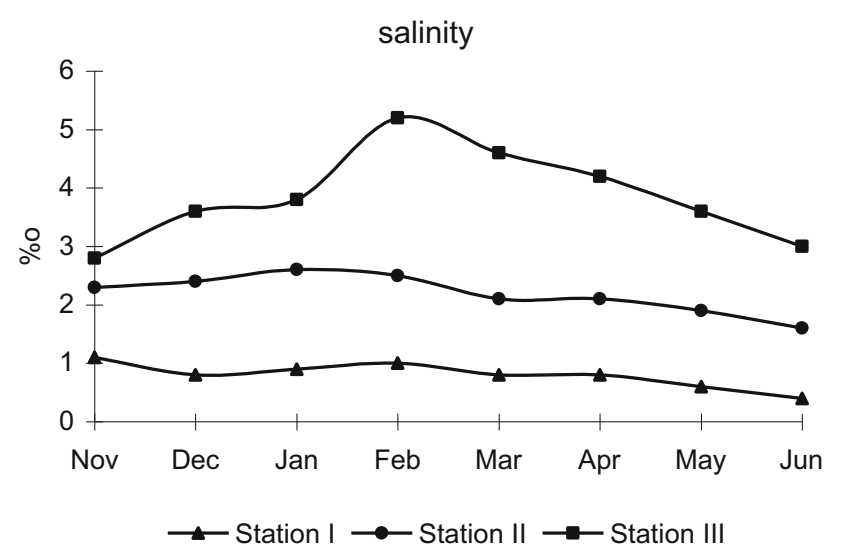

Diversity, evenness, dominance, and similarity indices

A summary of the diversity and dominance indices calculated for the three sites sampled is given in Table 4 . The taxon richness calculated as Margalef index $(d)$, was highest at Site 2, followed closely by Site 3. A much lower value of 4.64 was recorded at site 1 . Shannon diversity $\left(\mathrm{H}^{\mathrm{i}}\right)$ was significantly higher $(P<0.05)$ at Site 3 . Evenness values were similar at all sites but slightly higher at Site 3 (range from 0.714 to 0.759 at all sites). Simpson's dominance values were also similar at all sites.

Trophic structure of fish composition

The fish community was numerically dominated by detritivores $(39.0 \%)$ and planktinovores/microcarnivores $(35.0 \%)$, and predators $(23.0 \%)$ comprised a relatively high species number of sixteen (16) intermediate carnivores and twelve (12) predators (Table 5). Herbivores species (Oreochromis niloticus, Tilapia zillii) comprised $2.60 \%$. In terms of biomass, detritivores dominated the sample (52.3\% of the total biomass) due to the predominance of Tilapia guineensis which constituted $45 \%$ of the total biomass. The intermediate carnivores and the top-predators, despite their number ( 28 species), had a relatively low biomass proportion $(5.0 \% ; 8.4 \%)$.

Fisheries catch and yield

The fisheries catch for some commercially important species is shown in Table 6. Evaluation of the mean catch of the fishing gears from the fishing settlements gave the following values: traps $(0.15 \mathrm{~kg} / \mathrm{trap} / \mathrm{h})$; hook and line $0.18 \mathrm{~kg} / \mathrm{hook} / \mathrm{h}$; gill nets $(0.82 \mathrm{~kg} / \mathrm{net} / \mathrm{h})$. The mean catch per unit effort of the various gears was computed to be $0.39 \mathrm{~kg} / \mathrm{h}$ for the pooled data.

Length-weight relationship (LWR), condition factor and gonado-somatic index

The computed length-weight (LWR) for representative fish species is presented in Table 7. The LWR for all the fish correlated significantly with $r=0.789-0.9843$, and $p<0.001$. Most of the fish exhibited almost identical mean length exponent $(b)$. The regression exponent $(b)$, which signifies the type of growth, ranged between 2.164 and 4.437. When $b=3$ growth is considered isometric, meaning that the weight of the body is closely proportional to the cube of its length. Many species including Ilisha africana, Gerres melanopterus, Malapterurus electricus, and Parachanna africana recorded coefficient which did not differ remarkably from 3.0 indicating growth in such fishes to be isometric. Growth in Tilapia guineensis with $b=4.437$ (which exceeds 3.0) was positively allometric. The regression exponents for all other species were less than 3.0 indicating growth in these fishes to be negatively allometric. The mean condition factor $(k)$ computed for some selected species is also shown in Table 7 as well. The $k$ values ranged from 0.69 to 3.7 with a mean of 2.06. This was greater than unity $(k>1.0)$. The gonadosomatic indices (GSI) of some fish are also presented in Table 7. The GSI, which is a measure of reproductive investment, ranged from 0.42 to 4.33 . High values were 
Table 2 Fish assemblage in Ajijiguan creek, Niger Delta from November 2010 to June 2011 (+ sign indicates presence)

\begin{tabular}{|c|c|c|c|c|c|}
\hline \multirow[t]{2}{*}{ Family } & \multirow[t]{2}{*}{ Taxa } & \multirow[t]{2}{*}{ Species code } & \multicolumn{3}{|c|}{ Location } \\
\hline & & & Site 1 & Site 2 & Site 3 \\
\hline \multirow[t]{5}{*}{ Cichlidae } & Chromidotilapia guentheri (Sauvage, 1882) & Chro & + & & \\
\hline & Hemichromis fasciatus (Peters, 1857) & Hem & + & + & \\
\hline & Oreochromis niloticus (Trawavas, 1980) & Ore & + & + & \\
\hline & Tilapia guineensis (Günther, 1862) & Tig & & + & + \\
\hline & Tilapia zilli (Genvais, 1848) & Til & & + & + \\
\hline \multirow[t]{3}{*}{ Eleotridae } & Eleotris vitatta (Steindachner, 1870) & EleV & & & + \\
\hline & Eleotris senegalensis (Steindachner, 1870) & EleS & & + & + \\
\hline & Bostrychus africanus (Steindachner, 1878) & Bos & & + & + \\
\hline \multirow[t]{5}{*}{ Mugilidae } & Liza falcipinnis (Valenciennes, 1836) & $\operatorname{LizF}$ & & + & + \\
\hline & Mugil curema & MugC & & & + \\
\hline & Mugil bananensis & $M u g B$ & & + & + \\
\hline & Mugil cephalus (Linnaeus, 1758) & $\mathrm{MugCl}$ & & + & + \\
\hline & Liza grandisquamis (Valenciennes, 1836) & $\operatorname{LizQ}$ & & + & + \\
\hline \multirow[t]{4}{*}{ Mochokidae } & Synodontis eupterus (Baulenger, 1789) & SynE & + & & \\
\hline & Synodontis sorex (Baulenger, 1789) & SynS & + & + & \\
\hline & Synodontis nigrita (Valenciennes, 1840) & SynN & + & & \\
\hline & Synodontis budgetti (Valenciennes, 1840) & $\operatorname{Syn} B$ & + & + & \\
\hline \multirow[t]{4}{*}{ Clupeidae } & Ethmalosa fimbriata (Bowdich, 1825) & Eth & & & + \\
\hline & Pellonula afzellusi(Johnels, 1954) & $\mathrm{Pel}$ & + & & \\
\hline & IIisha africana (Bloch, 1795) & Iii & & + & + \\
\hline & Galeiodes sp. & Gal & & & + \\
\hline Cyprinodontidae & Epiplatys senegalensis (Steindachner, 1870) & Epi & + & & \\
\hline \multirow[t]{2}{*}{ Bagridae } & Auchenoglanis occidentalis (Cuvier and Valenciennes, 1840) & $A u c$ & + & + & \\
\hline & Chrysichthys nigrodigitatus (Lacepede, 1903) & Chry & + & + & \\
\hline \multirow[t]{2}{*}{ Channidae } & Parachanna obscura (Gunther, 1861) & ParO & + & + & \\
\hline & Parachanna africana (Gunther, 1861) & ParA & + & & \\
\hline \multirow[t]{3}{*}{ Characidae } & Brycinus nurse (Ruppel, 1832) & BryN & + & + & \\
\hline & Brycinus longipinnis (Gunther, 1864) & BryL & + & & \\
\hline & Brycinus leuciscus (Gunther, 1864) & BryLe & + & & \\
\hline \multirow[t]{3}{*}{ Clariidae } & Clarias macromystax (Gunther, 1864) & ClaM & + & + & \\
\hline & Clarias anguillaris (Linnaeus, 1758) & ClaA & + & + & \\
\hline & Clarias gariepinus (Burchell, 1822) & ClaG & + & + & \\
\hline \multirow[t]{4}{*}{ Mormyridae } & Gnathonemus senegalensis (Steidachner, 1879) & Gna & + & & \\
\hline & Hyperopisis bebe occidentalis (Lacepede, 1803) & Hyp & + & + & \\
\hline & Mormyrus rume (Cuvier and Valenciennes, 1846) & Mor & + & & \\
\hline & Petrocephalus bane ansorgei (Boulenger, 1902) & Pet & + & & \\
\hline Icthyboridae & Phago loricatus (Gunther, 1865) & Pha & & + & + \\
\hline Hepsetidae & Hepsetus odoe (Bloch, 1794) & Hep & + & & \\
\hline Malapteruridae & Malapterurus electricus (Gmelin, 1789) & Mal & + & & \\
\hline \multirow[t]{2}{*}{ Notopteridae } & Papyrocranus afer (Gunther, 1868) & Pap & + & + & \\
\hline & Xenomystus nigri (Gunther, 1868) & Xen & + & & \\
\hline Schilbeidae & Schilbe mystus (Linnaeus, 1758) & Sch & & & + \\
\hline \multirow[t]{2}{*}{ Lutjanidae } & Lutjanus goriensis (Bleeker, 1863) & $L u t G$ & & & + \\
\hline & Lutjanus agennes (Bleeker, 1863) & LutA & & + & + \\
\hline Distichodontidae & Distichodus rostratus (Gunther, 1864) & Dis & & & + \\
\hline Polypteridae & Erpetoichthys calabaricus(Smith, 1866) & Erp & & + & + \\
\hline Carangidae & Caranx hippos (Linnaeus, 1766) & Car & & & + \\
\hline
\end{tabular}


Table 2 continued

\begin{tabular}{|c|c|c|c|c|c|}
\hline \multirow[t]{2}{*}{ Family } & \multirow[t]{2}{*}{ Taxa } & \multirow[t]{2}{*}{ Species code } & \multicolumn{3}{|c|}{ Location } \\
\hline & & & Site 1 & Site 2 & Site 3 \\
\hline Cynoglossidae & Cynoglossus senegalensis & Cyn & & + & + \\
\hline \multirow[t]{2}{*}{ Gerreidae } & Gerres melanopterus & GerM & & & + \\
\hline & Gerres nigri & GerN & & + & + \\
\hline \multirow[t]{2}{*}{ Elopidae } & Elops lacerta (Valenciennes, 1846) & EloL & & & + \\
\hline & Elops senegalensis (Valenciennes, 1846) & EloS & & + & + \\
\hline Bothidae & Citharichthys stampflii & Cit & & & + \\
\hline \multirow[t]{2}{*}{ Pomadasydae } & Pomadasys jubelini (Cuvier, 1830) & PomJ & & & + \\
\hline & Pomadasys peroteti (Cuvier, 1830) & PomP & & & + \\
\hline Sphyraenidae & Sphyraena afra (Peters, 1844) & Sph & & + & + \\
\hline Total & & & 27 & & 29 \\
\hline
\end{tabular}

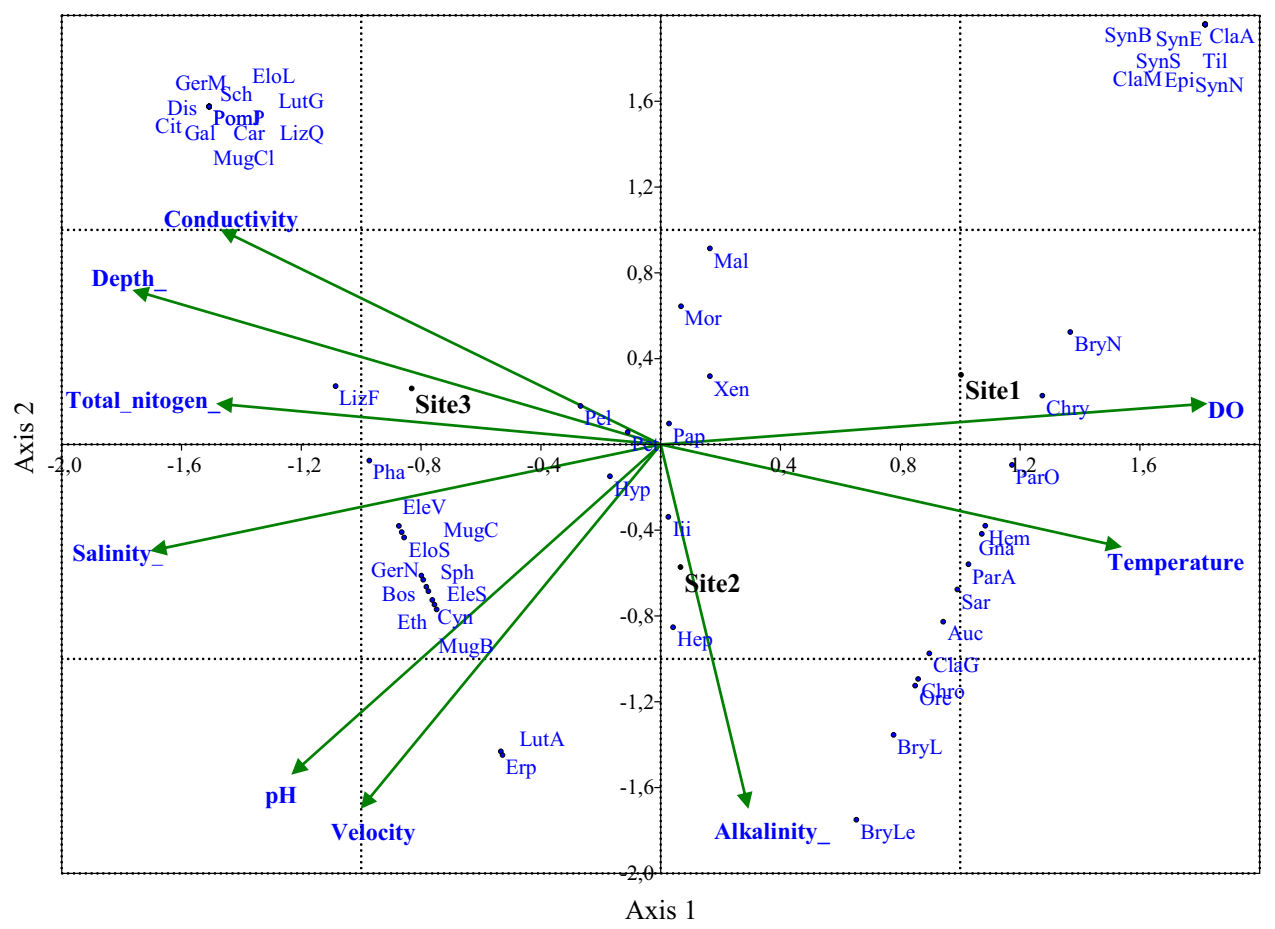

Fig. 3 CCA ordination diagram for sites and environmental relationships based on abundance data for 56 fish species in Ajijiguan creek, Niger Delta. Codes of taxa in Table 2

recorded in Chromidotilapia guentheri, Chrysichthys nigrodigitatus, Ethmalosa fimbriata, Tilapia zillii, Gerres melanopterus, and Parachanna africana.

\section{Discussion}

Water quality

The water chemistry of an aquatic ecosystem is dependent on the physical and geological features as well as the land use and catchment disturbances which in turn can influence the structure of aquatic communities 
Table 3 Weighted intraset correlations of environmental variables with the axes of canonical correspondence analysis (CCA) in Ajijiguan creek, Niger delta

\begin{tabular}{lcc}
\hline Variable & Axis 1 & Axis 2 \\
\hline Eigenvalue & 0.5499 & 0.1658 \\
Species-environment correlation & 0.92 & 0.90 \\
\% variation of species data explained & 76.84 & 23.16 \\
Temperature & $\mathbf{0 . 9 3 7 6 1 6}$ & -0.27539 \\
Depth & $\mathbf{- 0 . 9 0 2 8 4}$ & 0.360097 \\
Flow velocity & $\mathbf{- 0 . 5 5 7 4 5}$ & $\mathbf{0 . 8 7 0 1 8}$ \\
pH & $\mathbf{- 0 . 6 6 7 5 7}$ & $\mathbf{0 . 7 9 3 1 4}$ \\
DO & $\mathbf{0 . 9 9 9 2 3 4}$ & 0.114987 \\
Alkalinity & 0.044672 & $\mathbf{0 . 9 9 2 7 2}$ \\
Conductivity & $\mathbf{- 0 . 7 9 6 1 9}$ & $\mathbf{0 . 5 4 2 7 8}$ \\
Nitrate & $\mathbf{- 0 . 9 7 7 4}$ & 0.136494 \\
Salinity & $\mathbf{- 0 . 9 8 9 4 2}$ & -0.21987 \\
\hline
\end{tabular}

Values in bold indicate significant difference at $P<0.05$

Significance of the axes by Monte Carlo test is given: $P_{\text {values }}$ for Monte Carlo Permutation test. All canonical axes: $F=4.26$, $P<0.05$

Fig. 4 Dendrogram derived from the cluster analysis (Bray-Curtis similarity) of Ajijiguan sampling sites

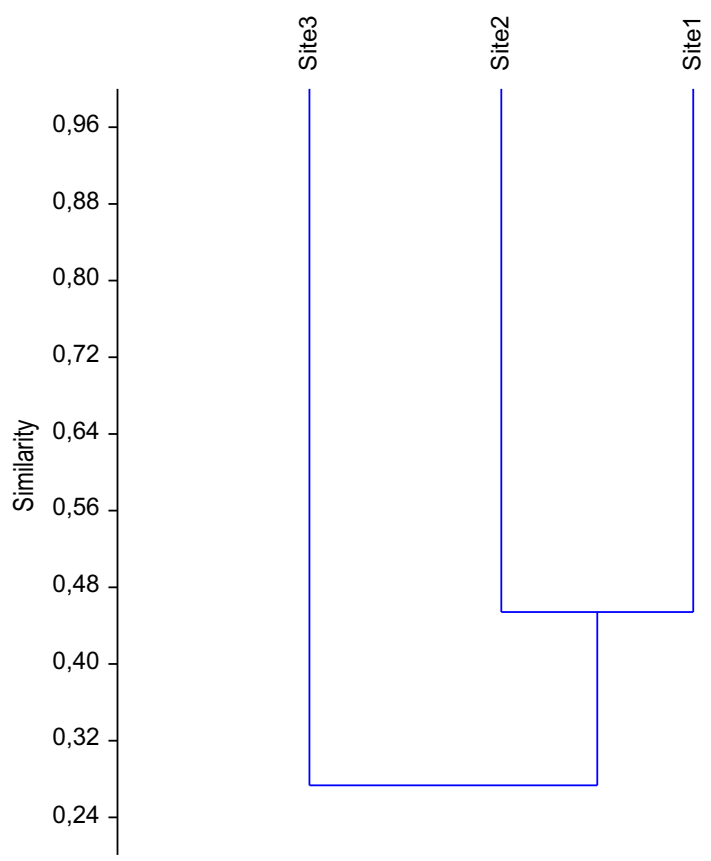

(Arimoro and Ikomi 2008; Arimoro et al. 2011). It is pertinent to determine these factors to proffer mitigation measures aimed at ensuring the survival and protection of aquatic species. Ajijiguan Creek connects the upstream freshwater River Ethiope to the downstream estuarine Benin River. High concentrations of dissolved oxygen, low nutrient, and BOD levels indicate that the water at Site 1 was only slightly disturbed by human activities, a suggestion confirmed by the distance of this site from human settlement. Higher nutrient, flow, and salinity levels were recorded at Site 2 than Site 1, and higher levels of nutrients, BOD, and electrical conductivity were measured at Site 3 than at the other sites, probably owing to the influx of washing detergents, deposition of organic wastes, and inputs of other pollutants in this reach. Salinity levels at Site 3 were relatively higher than those at Site 1 and 2. This was a reflection of the tidal influence of the Benin estuary that was more pronounced at Site 3. The higher salinity at Site 3, and most probably Site 2 is because of the marine water backflow and not necessarily a factor of human degradation. Differences in discharge, 
Table 4 Taxa richness, diversity, evenness, and dominance indices of fishes of Ajijiguan creek in the Niger Delta collected between November 2010 and December 2011

\begin{tabular}{llll}
\hline & Site 1 & Site 2 & Site 3 \\
\hline Number of Taxa & 30 & 36 & 35 \\
No. of individuals & 517 & 575 & 777 \\
Simpson dominance & 0.932 & 0.950 & 0.952 \\
Shannon diversity & 3.065 & 3.275 & 3.279 \\
Evenness_e^H/S & 0.714 & 0.734 & 0.759 \\
Margalef (Taxa richness) & 4.641 & 5.508 & 5.109 \\
\hline
\end{tabular}

flow velocity, and salinity between sites may have contributed immensely in determining the type and composition of fish species at the various sampling sites

Species assemblages

A total of 56 fish species were recorded in Ajijiguan creek during the entire study period representing 26 families. The relatively high species richness is, therefore, understood because the area represents one of the richest fishing zones in Nigeria (Ekeke et al. 2008; Obasohan and Oronsaye 2009). A greater number of the fish species were pelagic, which moved within the upper strata of the water column and are more likely to move away from environmental perturbation, whereas the demersals occupy the lower stratum and could be more susceptible to habitat perturbation. There were a total of 27 species of inland origin and 29 species of marine origin in the entire study stretch. Although on the average higher abundances of fish were recorded during the dry season than the wet season statistical test using $t$ test did not show any significant difference $(P>0.05)$. Consistent with this scenario, Soyinka and Ebigbo (2012) and Ogamba et al. (2014) recorded higher densities of fish in the dry season in Epe Lagoon and Odi River, Niger Delta, respectively. They suggested that the higher density of fish recorded in the dry season may be a response to the reduction of environmental stresses by the rain water dilution and migration of fish from the sea and surrounding water bodies into the creek. The gradual increase in salinity from the influx of the brackish Benin estuary during the wet season must have affected the abundance of the fish as well as increased human activities (Arimoro et al. 2011). Many of the fish species encountered in the study area are endemic not only to the Nigerian Coastal and inland waters but also to the entire West African Coast. For example, the shoaling pelagic shad (Ethmalosa fimbriata) or bonga and Tilapia guineensis are found along the entire West African Coast, along the Coast of Nigeria, Cameroun and estuaries to the mouth of River Congo (Arimoro et al. 2006; Soyinka and Ebigbo 2012; Oribhabor and Ogbeibu 2012; Ogamba et al. 2014).

Canonical correspondence analysis clearly separated the less impacted from the most impacted sites and showed that many environmental factors were significantly associated with the fish fauna of Ajijiguan Creek. Salinity, nitrate concentration, and electrical conductivity were higher at Site 3 than at the other sites, whereas Site 1 had higher dissolved oxygen levels and lower salinities than other sites. The combination of variables might be used to identify and describe the multiple-scale stressors. The correlations of many individual environmental variables with the axes were relatively high for CCA but were not statistically significant. However, these estimated significances may be the result of the unmeasured environmental variables. Site I was an extreme outlier in our ordination analysis, since it had a very different fish community restricted to freshwater species only such as Hemichromis fasciatus, Clarias gariepinus, Parachanna africana, P. obscura, etc. The mean salinity value of this site was also significantly lower than the other two sites thus favoring the existence of species that are intolerant to increasing salinity content. The red snapper, Lutjanus goriensis, Caranx hippos, Schilbe mystus, Mugil curema, Ethmalosa fimbriata, Galeiodes species, etc., were only found in Site 3 as shown by the CCA multivariate analysis (Fig. 3). In accordance with our findings, Ekeke et al. (2008) reported that the typical habitats of these species are the transition zones of brackish waters and seawater. 
Trophic structure of fish composition

The fish community was numerically dominated by detritivores, planktinovores/microcarnivores and predators. Herbivores species (Oreochromis niloticus, Tilapia zillii) comprised $2.60 \%$. In terms of biomass, detritivores dominated the sample (52.3\% of the total biomass) due to the predominance of Tilapia guineensis which constituted $45 \%$ of the total biomass. The intermediate carnivores and the top-predators, despite their number (28 species), had a relatively low biomass proportion $(5.0 \% ; 8.4 \%)$. Relative to their economic value, fish were categorized according to their commercial value: (1) fish of high commercial value (HC), (2) fish of moderate commercial value (MC), and (3) fish with no commercial value (NC) and is not utilized as food nor is it sold in the fish market. From the fish sampled, about $80 \%$ had a high economic value, from which $82 \%$ were juveniles and adults. Only one species (Epiplatys senegalensis) of small size had no commercial value. This indicates that the creek is under a multi-species fishery where about $94 \%$ of the fish species are exploited. The data do demonstrate some similar trends of trophic structures in different mangrovelined estuaries (Oribhabor and Ogbeibu 2012; Adite et al. 2013). In other words, fishes have evolved to better exploit the large mass of mangrove leaves which falls and decays in permanence in the coastal zone system generating a huge amount of substrate (Adite et al. 2013). Such substrate harbors plenty of biotic and abiotic foods. In contrast, in term of abundance, top predators tend to be reduced even though the number of species seems to be relatively high.

\section{Fisheries catch and yield}

The catch rate for the selected commercially important species was generally moderate compared with low catch reported during the peak period of rainfall in Nigeria (Abowei et al. 2010). In addition, the high catch rate could be attributed to the moderately large size of the fish. This is because a large proportion of the fish examined were generally of a moderate to large size and a few were juveniles harvested indiscriminately with no selective gears. The mean catch per unit effort of the various gears computed as $0.39 \mathrm{~kg} / \mathrm{h}$ for the pooled data is quite high. Any environmental degradation is likely to affect the catch rates. For example, if the fishing gears are fouled by contact with contaminants, e.g. oil/effluent, they would become more visible to fish leading to fish avoidance.

It is clear that most of these commercially and scientifically important fish species (C. nigrodigitatus, Lutjanus sp., Pomadasys species, Liza sp., Mugil sp., Tilapia sp., Sarotherodon sp. and E. fimbriata) occurring in brackish waters in the Niger Delta of Nigeria can be landed all the year round by artisanal fishers, but there are months when they are more abundant. Tobor (1992) reported that most of these artisanal fisheries are dry season fishery, that is, the fish are most abundant during the dry season. The fingerlings of some of the brackish water fish species occur in large quantities in some months. The various mullet species (Liza spp. and Mugil spp.) spawn at different times of the year; they appear to be abundant all year-round. The moderately high number of fish reported in this study supports the above claims. In this study it was observed that $E$. fimbriata was abundant in the catches in the month of January. Nsentip (1987) reported that E. fimbriata was most abundant from the beginning of the dry season, that is, from November, which is actually the beginning of the Bonga (E. fimbriata) fishing and ending in May in the Cross river estuary (brackish water); Also, January to March portion represents the peak period of the fishing with no catch at all in August to October. Nsentip (1987) also observed that in certain parts of the coast, and in particular the open sea off the Niger Delta, E. fimbriata is caught all-year round whenever the canoes venture to sea. In the FAO (1997) publication, it was explained that the occurrence of E. fimbriata near the shore at the beginning of the fishing season was linked with salinity of the water. When the brackish water of low salinity prevailed, no Ethmalosa spp was caught, but as soon as the estuarine water was replaced by clear, salt seawater, good catches were obtained. This explanation also goes for all the fish species caught during the dry season mentioned above.

Length-weight relationship, condition factor and gonado-somatic index

Many species including Ilisha africana, Gerres melanopterus, Malapterurus electricus, and Parachanna africana recorded coefficients which did not differ remarkably from 3.0 indicating growth in such fishes to be isometric. Growth in Tilapia guineensis with $b=4.437$ (which exceeds 3.0) was positively allometric. The 
Table 5 Classification of fish caught at Ajijiguan creek into trophic categories, relative abundance and fisheries importance

\begin{tabular}{|c|c|c|c|}
\hline Trophic category and species & Relative abundance (\%) & Life history stage & Fisheries importance \\
\hline \multicolumn{4}{|l|}{ Detritivores } \\
\hline Brycinus leuciscus & 0.13 & $\mathrm{~J}$ & $\mathrm{MC}$ \\
\hline Brycinus nurse & 0.23 & $\mathrm{~J}$ & $\mathrm{MC}$ \\
\hline Chrysichthys nigrodigitatus & 1.25 & $\mathrm{~J} / \mathrm{A}$ & $\mathrm{HC}$ \\
\hline Distichodus rostratus & 0.21 & $\mathrm{~J} / \mathrm{A}$ & $\mathrm{MC}$ \\
\hline Erpetoichthys calabaricus & 0.02 & $\mathrm{~J} / \mathrm{A}$ & $\mathrm{MC}$ \\
\hline Ethmalosa fimbriata & 8.22 & $\mathrm{~J} / \mathrm{A}$ & $\mathrm{HC}$ \\
\hline Gnathonemus senegalensis & 0.51 & $\mathrm{~J} / \mathrm{A}$ & $\mathrm{HC}$ \\
\hline Liza falcipinnis & 5.02 & $\mathrm{~J}$ & $\mathrm{HC}$ \\
\hline Liza grandisquamis & 0.41 & $\mathrm{~J} / \mathrm{A}$ & $\mathrm{HC}$ \\
\hline Mormyrus rume & 0.22 & A & $\mathrm{HC}$ \\
\hline Mugil bananensis & 0.22 & A & $\mathrm{HC}$ \\
\hline Mugil cephalus & 0.63 & A & $\mathrm{HC}$ \\
\hline Mugil curema & 0.91 & $\mathrm{~J} / \mathrm{A}$ & $\mathrm{HC}$ \\
\hline Tilapia guineensis & 19.92 & $\mathrm{~J} / \mathrm{A}$ & $\mathrm{MC}$ \\
\hline Synodontis budgetti & 0.62 & $\mathrm{~J} / \mathrm{A}$ & $\mathrm{HC}$ \\
\hline Synodontis eupterus & 0.04 & A & $\mathrm{HC}$ \\
\hline Synodontis nigrita & 0.28 & $\mathrm{~J} / \mathrm{A}$ & $\mathrm{HC}$ \\
\hline Synodontis sorex & 0.24 & $\mathrm{~J} / \mathrm{A}$ & $\mathrm{HC}$ \\
\hline \multicolumn{4}{|l|}{ Planktinovores/microcarnivores } \\
\hline Auchenoglanis occidentalis & 1.40 & $\mathrm{~J} / \mathrm{A}$ & $\mathrm{HC}$ \\
\hline Chromidotilapia guentheri & 3.12 & A & $\mathrm{HC}$ \\
\hline Epiplatys senegalensis & 2.09 & $\mathrm{~J}$ & $\mathrm{NC}$ \\
\hline Citharichthys stampflii & 3.07 & $\mathrm{~J} / \mathrm{A}$ & $\mathrm{MC}$ \\
\hline Pellonula afzellusi & 4.18 & $\mathrm{~J} / \mathrm{A}$ & $\mathrm{MC}$ \\
\hline Gerres melanopterus & 17.09 & $\mathrm{~J} / \mathrm{A}$ & $\mathrm{HC}$ \\
\hline Gerres nigri & 4.11 & $\mathrm{~J} / \mathrm{A}$ & $\mathrm{HC}$ \\
\hline \multicolumn{4}{|l|}{ Herbivores } \\
\hline Tilapia zillii & 1.40 & $\mathrm{~J} / \mathrm{A}$ & $\mathrm{HC}$ \\
\hline Oreochromis niloticus & 1.20 & $\mathrm{~J} / \mathrm{A}$ & $\mathrm{HC}$ \\
\hline \multicolumn{4}{|l|}{ Intermediate carnivores } \\
\hline Clarias macromystax & 5.06 & A & $\mathrm{HC}$ \\
\hline Caranx hippos & 0.02 & $\mathrm{~J} / \mathrm{A}$ & $\mathrm{HC}$ \\
\hline Cynoglossus senegalensis & 0.06 & A & $\mathrm{MC}$ \\
\hline Elops lacerta & 0.06 & A & $\mathrm{HC}$ \\
\hline Elops senegalensis & 0.06 & A & $\mathrm{HC}$ \\
\hline Clarias anguillaris & 0.30 & A & $\mathrm{HC}$ \\
\hline Clarias gariepinus & 0.06 & A & $\mathrm{HC}$ \\
\hline Hemichromis fasciatus & 6.29 & $\mathrm{~J} / \mathrm{A}$ & $\mathrm{MC}$ \\
\hline Malapterurus electricus & 0.06 & A & $\mathrm{MC}$ \\
\hline Papyrocranus afer & 0.06 & A & $\mathrm{MC}$ \\
\hline Petrocephalus bane ansorgei & 0.22 & $\mathrm{~J}$ & $\mathrm{MC}$ \\
\hline Phago loricatus & 0.22 & $\mathrm{~J}$ & $\mathrm{MC}$ \\
\hline Pomadasys jubelini & 0.05 & $\mathrm{~J} / \mathrm{A}$ & $\mathrm{HC}$ \\
\hline Pomadasys peroteti & 0.01 & $\mathrm{~J} / \mathrm{A}$ & $\mathrm{HC}$ \\
\hline Galeiodes sp. & 0.08 & A & $\mathrm{HC}$ \\
\hline Xenomystus nigri & 0.48 & $\mathrm{~J}$ & $\mathrm{MC}$ \\
\hline
\end{tabular}


Table 5 continued

\begin{tabular}{llll}
\hline Trophic category and species & Relative abundance $(\%)$ & Life history stage & Fisheries importance \\
\hline Predators & & & HC \\
Bostrychus africanus & 6.64 & J/A & MC \\
Eleotris daganensis & 0.04 & $\mathrm{~A}$ & $\mathrm{MC}$ \\
Eleotris senegalensis & 0.08 & $\mathrm{~J} / \mathrm{A}$ & $\mathrm{MC}$ \\
Eleotris vitatta & 0.08 & $\mathrm{~J} / \mathrm{A}$ & $\mathrm{MC}$ \\
Hepsetus odoe & 0.88 & $\mathrm{~J}$ & $\mathrm{HC}$ \\
IIisha Africana & 0.42 & $\mathrm{~A}$ & $\mathrm{HC}$ \\
Lutjanus agennes & 0.05 & $\mathrm{~J} / \mathrm{A}$ & $\mathrm{HC}$ \\
Lutjanus goriensis & 0.14 & $\mathrm{~J} / \mathrm{A}$ & $\mathrm{HC}$ \\
Parachanna africana & 1.08 & $\mathrm{~A}$ & $\mathrm{HC}$ \\
Parachanna obscura & 0.78 & $\mathrm{~A}$ & $\mathrm{MC}$ \\
Schilbe mystus & 0.08 & $\mathrm{~J} / \mathrm{A}$ & $\mathrm{MC}$ \\
Sphyraena afra & 0.52 & & \\
Total & 100 & &
\end{tabular}

Detritivores and planktinovores/microcarnivores dominated the sample

$J$ Juvenile, $A$ adult, $H C$ highly commercial, $M C$ moderately commercial, $N V$ no value

regression exponents for all other species were less than 3.0 indicating growth in these fish to be negatively allometric. The $k$ values ranged from 0.69 to 3.7 with a mean of 2.06. This was greater than unity $(k>1.0)$ and depicts good body condition for fish assemblage in the study area. The condition factor expresses the relative robustness of a fish. The good body condition for most of the fish indicates less perturbation from environmental degradation and abundance of food resource base, which ensured good body fitness and growth. It is also an indication that other environmental variables including DO were very favorable to the fish.

High values of GSI were recorded in Chromidotilapia guentheri, Chrysichthys nigrodigitatus, Ethmalosa fimbriata, Tilapia zillii, Gerres melanopterus, and Parachanna africana. The high GSI values in these fish indicate higher reproductive investment during the dry season with the obvious implication that yields per recruit in the following year would be high for such fish. However, fish with low GSI apparently made low reproductive investment during the period or recovered from egg laying. Low reproductive investment could be due to environmental perturbation or alteration in resources with the result that yield per recruit in the following year would be low because of poor gonadal development.

Food items of fish species

Fish are regarded as highly successful in their feeding habit, because of the ability to utilize varied food items. Their feeding habits vary from predators through plankton to detritus feeders. The physicochemical characteristics determine the composition of fish food items in a given environment. Plankton and aquatic vegetation and fish parts were found in the stomach of many fish in this study perhaps explaining their occurrence in the mangrove region. Adite et al. (2013) also obtained similar results in the study of fish assemblages in the degraded mangrove ecosystems of Benin, West Africa.

\section{Conclusion}

The Niger Delta contains rivers, creeks, swamps, and wetlands which are valued globally for their biodiversity. The study area represents one of the rich fishing zone in Nigeria with lots of fishery activities (subsistence and artisanal fishing) going on. This study provides useful information on the present status of the water quality and a baseline survey of fish fauna in the creek, forming the foundation for long-term assessment and for the use of fish as bioindicators for environmental monitoring and management of this system. 
Table 6 Average composition of fish landing based on survey of boat landing in the fishing settlements of Ajijiguan creek, Niger Delta

\begin{tabular}{lcc}
\hline Fish species & Mean catch/Fu (kg) & \% composition \\
\hline Tilapia guineensis & 32.34 & 24.18 \\
Ethmalosa fimbriata & 12.48 & 9.33 \\
Gerres melanopterus & 12.24 & 9.15 \\
Tilapia zillii & 2.43 & 1.82 \\
Clarias macromystax & 16.20 & 12.11 \\
Hemichromis fasciatus & 2.10 & 1.57 \\
Parachanna africana & 0.08 & 0.06 \\
Chromidotilapia guentheri & 1.20 & 0.90 \\
Chrysichthys nigrodigitatus & 14.8 & 11.06 \\
Hepsetus odoe & 0.32 & 0.23 \\
IIisha africana & 1.48 & 1.10 \\
Bostrychus africanus & 12.20 & 9.12 \\
Oreochromis niloticus & 0.60 & 0.44 \\
Malapterurus electricus & 1.26 & 0.94 \\
Papyrocranus afer & 0.76 & 0.57 \\
Pellonula afzellusi & 0.83 & 0.62 \\
Liza falcipinnis & 14.20 & 10.61 \\
Liza grandisquamis & 8.25 & 6.17 \\
& 133.8 &
\end{tabular}

Table 7 Computed LWR for representative fish species in Ajijiguan creek

\begin{tabular}{llcll}
\hline Fish species & Total length $(\mathrm{cm})$ & Weight $(\mathrm{g})$ & Condition factor $(K)$ & Gonado somatic index $(\mathrm{GSI})$ \\
\hline Tilapia guineensis & 15.2 & 100 & 2.85 & 3.04 \\
Ethmalosa fimbriata & 21.2 & 270 & 2.83 & 3.72 \\
Gerres melanopterus & 28.5 & 298 & 1.29 & 3.86 \\
Tilapia zillii & 14.9 & 101 & 3.05 & 3.78 \\
Clarias macromystax & 43.8 & 1,300 & 1.55 & 1.14 \\
Hemichromis fasciatus & 21.4 & 200 & 2.04 & 0.68 \\
Parachanna Africana & 36 & 320 & 0.69 & 3.24 \\
Chromidotilapia guentheri & 11.5 & 45 & 2.96 & 4.33 \\
Chrysichthys nigrodigitatus & 34.2 & 1,200 & 3.00 & 3.62 \\
Hepsetus odoe & 26 & 218 & 1.24 & 1.40 \\
IIisha africana & 18 & 67 & 1.15 & 0.92 \\
Bostrychus africanus & 23.4 & 324 & 2.53 & 0.98 \\
Oreochromis niloticus & 28 & 830 & 3.78 & 1.04 \\
Malapterurus electricus & 36 & 870 & 1.86 & 0.82 \\
Papyrocranus afer & 38.6 & 398 & 0.69 & 0.42 \\
Pellonula afzellusi & 11 & 24 & 1.80 & 0.64 \\
Liza falcipinnis & 18.8 & 102 & 1.54 & 0.82 \\
Liza grandisquamis & 16 & 89 & 2.17 & 2.42 \\
Mean & & & 2.06 & \\
\hline
\end{tabular}

Open Access This article is distributed under the terms of the Creative Commons Attribution License which permits any use, distribution, and reproduction in any medium, provided the original author(s) and the source are credited. 


\section{References}

Abowei JFN, Davies OA, Eli AA (2010) Physico-chemical characteristics, morphology and abundance of five fish species from Nkoro River, Niger delta, Nigeria. Int J Pharm Biosci 1(2):1-11

Adite A, TokoI I, Gbankoto A (2013) Fish assemblages in the degraded mangrove ecosystems of the coastal zone Benin, West Africa: implications for ecosystem restoration and resources conservation. J Environ Prot 4:1461-1475

APHA (American Public Health Association) (1998) Standard methods for examination of water and wastewater, 20th edn. American Public Health Association, American Water Works Association and Water and Environment Federation, Washington, DC

Arimoro FO, Ikomi RB (2008) Response of macroinvertebrates to abattoir wastes and other anthropogenic activities in a municipal stream in the Niger Delta, Nigeria. Environmentalist 28:85-98. doi:10.1007/s10669-007-9033-8

Arimoro FO, Ikomi RB, Osalor EC (2006) The impact of sawmill wood wastes on the water quality and fish communities of Benin River, Niger Delta area, Nigeria. Int J Sci Technol 2(1):1-12

Arimoro FO, Ikomi RB, Ajuziego IO, Nwadukwe FO (2011) Temporal and spatial variability in the structure of macroinvertebrate communities and environmental variables of a Niger delta creek. Afr J Aquat Sci 36:57-66

Bagenal TB (1978) Aspects of fish fecundity. In: Gerking SD (ed) Ecology of freshwater fish production. Blackwell Scientific Publications, Oxford, pp 75-101

Barber BJ, Blake NJ (2006) Reproductive physiology. In: Shumway SE, Parsons GJ (eds) Scallops: biology, ecology, and aquaculture, 2nd edn. Elsevier, Amsterdam, pp 357-416

Delgado C, Wada N, Rosegrant M, Meijer S, Ahmed M (2003) Fish to 2020: supply and demand in changing global markets. International Food Policy Research Institute and Penang; World Fish Center, Washington, DC

Ekeke BA, Davies OA, Alfred-Ockiya JF (2008) Sand dredging impact on the fish catch in Bonny River Estuary, Nigeria. Environ Res J 2(6):299-305

FAO (1997) Fisheries by catch and discards Committee on fisheries. Twenty-second session. FAO, Rome

FAO (2003) The State of Food Insecurity in the World (SOFI 2003). Food and Agriculture Organization, Rome, p 36

Gordon ND, McMahon TA, Finlayson BL (1994) Stream hydrology, an introduction for ecologists. John Wiley, New York

Hammer Ø, Harper DAT, Ryan PD (2001) PAST: paleontological statistics software package for education and data analysis. Palaeontol Electron 4(1): 9. http://palaeo-electronica.org/2001_1/past/issue1_01.htmm

Hyslop EJ (1980) Stomach content analysis. A review of methods and their application. J Fish Biol 17:411-429

Jckel K (1986) Finite sample properties and asymptotic efficiency of Monte Carlo tests. J Appl Econom 14:85-118

Nsentip NU (1987) Review of Bonga (Ethmalosa fimbrata) fisheries of the Cross River State, Nigeria. In: Proceedings of the 4th Annual Conference of the Fisheries Society of Nigeria (FISON), Port Harcourt

Obasohan EE, Oronsaye JAO (2009) Impact of urban wastewaters on the diversity and abundance of the fish population of Ogba River in Benin City, Nigeria. Afr J Biotechnol 8(10):2242-2250

Ogamba EN, Abowei JFN, Onugu A (2014) Finfish species distribution and seasonality in Odi River, Niger Delta, Nigeria. J Aquat Sci 29:13-22

Oribhabor J, Ogbeibu AE (2012) The food and feeding habits of fish species assemblage in a Niger Delta Mangrove Creek, Nigeria. J Fish Aquat Sci 7(2):134-149

Salgado JP, Cabral HN, Costa MJ (2007) Spatial and temporal distribution patterns of macrozoobenthos assemblages in the salt marshes of Tejo Estuary (Portugal). Hydrobiologia 587:225-239

Soyinka OO, Ebigbo CH (2012) Species Diversity and Growth Pattern of the Fish Fauna of Epe Lagoon, Nigeria. J Fish Aquat Sci 7(6):392-401

terBraak CJK, Smilauer P (2002) CANOCO Reference Manual and Canoco Draw for Windows User's Guide: Software for Canonical Community Ordination (Version 4.5). Microcomputer Power, Ithaca, pp 1-500

Thieme ML, Abell R, Stiassny MLJ, Skelton P (2005) Freshwater ecoregions of Africa and Madagascar. A conservation assessment. Island Press, Washington, pp 1-431

Tobor JG (1992) Fin and shellfish of conservation interest in Nigeria. NIOMR Tech Paper No 79:1-23

World Fish Center (2005) Fish and Food Security in Africa. World Fish Center, Penang. Fish and Food Security in Africa. http:// www.worldfishcenter.org/resource_centre/Fish\&FoodSecurity\%20in\%20Africa.pdf 